\title{
Assessment of Groundwater Contamination Hazard by Nitrate in Samas Area, Bantul District, Yogyakarta, Indonesia
}

\author{
Thilavanh Souvannachith*1, Doni Prakasa Eka Putra ${ }^{2}$, and Heru Hendrayana ${ }^{2}$ \\ ${ }^{1}$ Department of Water Resources Engineering, Faculty of Engineering, National University of Lao \\ ${ }^{2}$ Department of Geological Engineering, Faculty of Engineering, Gadjah Mada University, Yogyakarta, Indonesia
}

\begin{abstract}
Groundwater resource is an essential for various purposes in Bantul district, Yogyakarta Special Province, Indonesia, especially on Poncosari village where the water supply are depending on shallow groundwater resources. On this village, most of the houses using dug wells to provide their water needs and applying inappropriate on-site sanitation system, however there are also difference land uses. This condition increase the hazard of groundwater contamination by fecal coli bacteria and nitrate. Therefore, this research aims in term of three main objectives: firstly, to know the level of nitrate concentration in groundwater, secondly, to assess groundwater vulnerability and thirdly, to assess the level of groundwater contaminant hazard. Hydrogeology observation was conducted and 47 water samples (44 groundwater samples and 3 surface water samples) were collected from different land use type and analyze for nitrate $\left(\mathrm{NO}_{3}^{-}\right)$content. Methodology used to assess the groundwater vulnerability was Simple Vertical Vulnerability method and the groundwater contamination hazard built based on the combination of groundwater vulnerability and nitrate loading potential map. Results show that groundwater concentrations of nitrate range from $0.09-74.80 \mathrm{mg} / \mathrm{L}$ and the highest concentration found in the settlement area. Assessment of groundwater vulnerability reveals three areas of moderate, moderate high and high classes of vulnerability due to shallow groundwater and the sandy dominated overlying material in the study area. Combination of groundwater vulnerability and nitrate loading potential map indicated that groundwater contaminant hazard of nitrate range from low to high class. High class of hazard located in the settlement area, and low hazard of nitrate contamination found in the irrigated rice field area.
\end{abstract}

Keywords: Nitrate - Groundwater vulnerability - Groundwater contaminant loading · Groundwater contaminant hazard · Bantul · Indonesia.

\section{INTRODUCTION}

Poncosari village is located on Samas area, Srandakan Sub-District, Bantul District, Yogyakarta Province, in which water supply for communities are depending on shallow groundwater resources. Abstraction of groundwater commonly using dug wells due to very shallow groundwater condition of less than $4 \mathrm{~m}$ from the ground surface (Kabahari, 2014). The land uses in the research area are dominated by

\footnotetext{
${ }^{*}$ Corresponding author: T. SOUVANNACHITH, Department of Water Resources Engineering, Faculty of Engineering, National University of Lao. E-mail: thilavanh@hotmail.fr
}

agriculture, settlement and beach sand dunes area. Groundwater contamination by nitrate is the major problem throughout the world, often occurring as the result of inappropriate on-site sanitation system (ARGOSS, 2001, Morris et al., 2003, Putra, 2010). In the research area, application of inappropriate on-site sanitation are common and therefore hazard of nitrate contamination to groundwater is probably high. Nitrate concentration in well water in Yogyakarta, Indonesia, and its surroundings tend to increase rapidly from time to time, and it proves to be associated with an elevated risk of colorectal cancer (Fathmawati et al., 2017). 
The potential of nitrate hazard to groundwater can be worst as the study area is located in Wates Formation and coastal sand dunes (MacDonald \& Partners, 1984). Wates Formation consist of clay, silt, fine to medium sand and gravel. Moreover coastal sand dunes consist of fine to coarse sand sediment. Those lithological formation allow high vertical velocity of contaminant movement in the unsaturated zone. However, recent report relate to nitrate content on groundwater under settlement area in the study area are only beween 0.014 to 3.919 $\mathrm{mg} / \mathrm{L}$ (Gunadarma, 2016). Based on the above facts, the aim of this research are: (1) to know the level of nitrate concentration in groundwater under different land uses, (2) to assess groundwater vulnerability and (3) to assess the groundwater contaminant hazard in the research area.

\section{STUdy AREA}

The study area is located in Samas area, Poncosari village, Srandakan sub-district on the southern part of Bantul dstrict, Special Province of Yogyakarta, Indonesia (Figure 1). The study area covered approximately $6.60 \mathrm{~km}^{2}$. The boundary is next to the Progo River at the west side, Sanden sub-district at the east and the India Ocean at the south.

Land use in the study area were simply classified into four categories: settlement, irrigation rice field area, non-irrigation agricultural area and sand dune area (beach area) (se Figure 2). Settlement refers mainly to area where people are settling down which covered around $32 \%$ of study area. Irrigation rice field covered from the north to the middle part around $36 \%$ of the study area. Non- irrigation agricultural area are composed of rice field, plantation field, corn field and shrimp ponds which covered around $20 \%$ of the study area and the rest $12 \%$ is the natural sand dune area or beach area.

\section{TheORETICAL BACKGROUND}

\subsection{Groundwater vulnerability}

Groundwater vulnerability is a term to show a susceptibility of aquifer from contamination. There are two terms of groundwater vulnerability; intrinsic and specific vulnerability. The intrinsic vulnerability depends on the natural attenuation capacity of the unsaturated and sat-
Table 1: SVV values for percolation rate factor $\left(W_{u}\right)$ according to the class of recharge rate $(\mathrm{Pu}-$ tra, 2007).

\begin{tabular}{cc}
\hline $\begin{array}{c}\text { Recharge rate } \\
(\mathrm{mm} / \text { year })\end{array}$ & $\begin{array}{c}\text { Rank of groundwater } \\
\text { protection }\end{array}$ \\
\hline$<50$ & 14 \\
$50-100$ & 10 \\
$100-200$ & 8 \\
$200-300$ & 6 \\
$300-400$ & 5 \\
$400-500$ & 4 \\
$500-600$ & 3 \\
$>600$ & 2 \\
\hline
\end{tabular}

urated zone. Meanwhile the specific vulnerability is being used to determine the vulnerability of groundwater as the combination between intrinsic factor and specific land uses or specific contaminant or group of contaminants. The effectiveness of unsaturated zone to reduce the contamination can be estimated based on the residence time of percolating water in the unsaturated zone. This is the main behind the development of Simple Vertical Vulnerability (SVV) method to assess groundwater vulnerability (Putra, 2007).

The SVV method is useful on shallow groundwater condition (depth to groundwater $<20 \mathrm{~m}$ ) and the aquifer built by quarternary deposits. This method is based on three parameters, which are: depth to groundwater, overlying materials and groundwater recharge rate. Detail explanation of SVV method can be found on Putra (2007). To classify groundwater vulnerability class, this method applying point count system for each parameters (See Table 1,2 and 3). The formula of calculation is as following:

$$
P_{T}=L_{a}+Z+W_{u}
$$

Where: $P_{T}$ : Final score of protective effectiveness of the unsaturated zone; $L_{a}$ : $\mathrm{Av}-$ erage points of the soil/rock cover; $L_{a}=$ $\frac{L_{1}+L_{2}+L_{3}+\cdots+L_{n}}{N} ; Z$ : Points of the thickness of unsaturated zone; $W_{u}$ : Points of the recharge rate $N$ : Number of the overlying layers. 


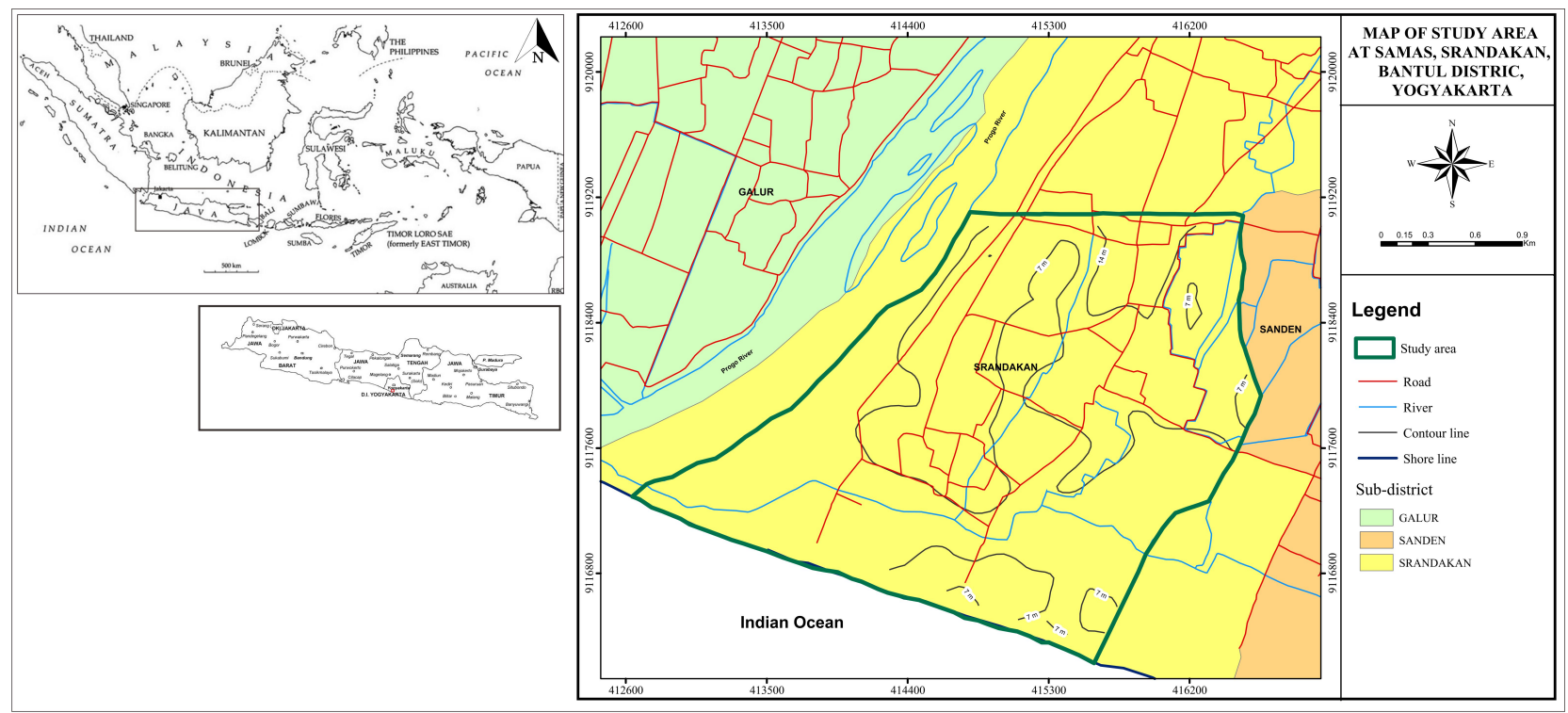

Figure 1: Location of the study area.

Table 2: SVV values for overlying material factor $(L)$ according to soils/unconsolidated rock type (Putra, 2007).

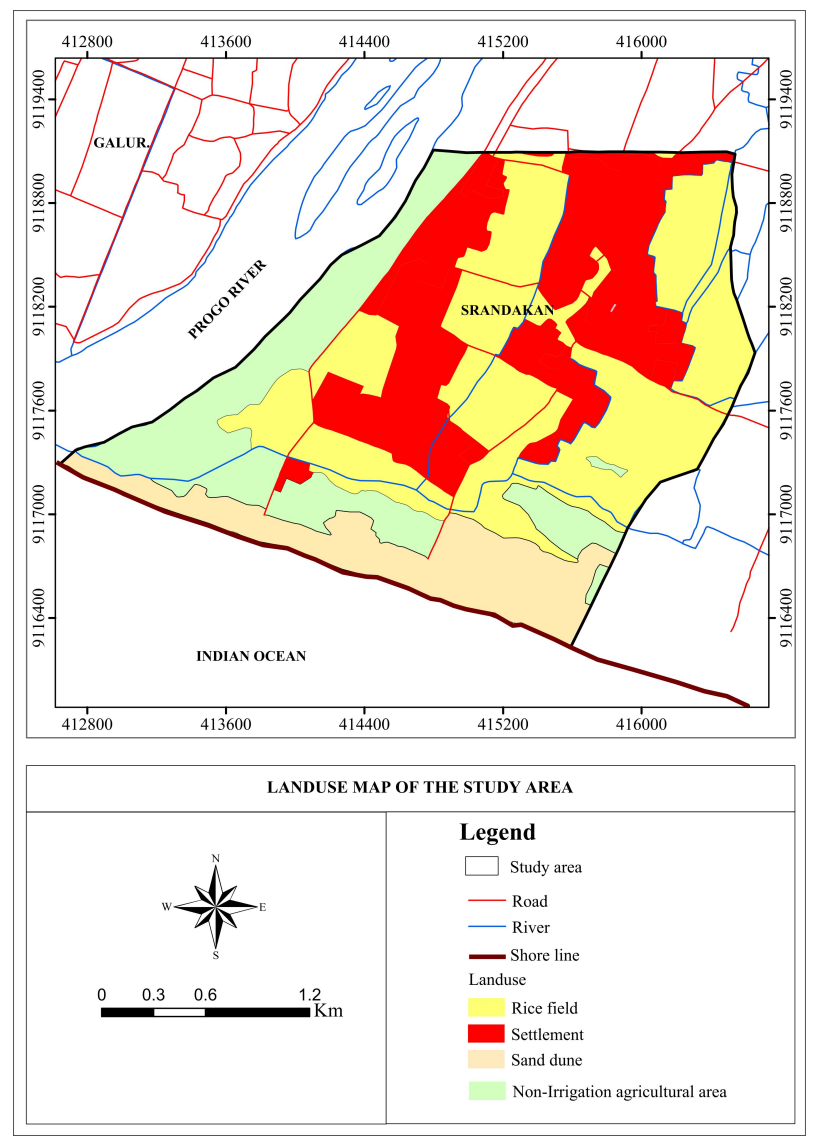

Figure 2: Land uses in the research area.

\begin{tabular}{ccc}
\hline $\begin{array}{c}\text { Type of soils/ } \\
\text { unconsolidated } \\
\text { rocks }\end{array}$ & $\begin{array}{c}\text { Code of } \\
\text { soil/ rock } \\
\text { texture }\end{array}$ & $\begin{array}{c}\text { Rank of } \\
\text { ground- } \\
\text { water } \\
\text { protection }\end{array}$ \\
\hline $\begin{array}{c}\text { Gravel - gravelly } \\
\text { sand }\end{array}$ & Gs, SG & 8 \\
Coarse - medium & mS, mSgs & 11 \\
sand & mSfs, fSms, & 16 \\
Fine - medium sand & Su & 24 \\
Fine sand & Sl, St, fS & 24 \\
Clayey/silty/loamy & Su, St, Us & 24 \\
sand & Ls, Slu, Uls & 29 \\
Sandy silt loam & Lu, Uu, Ut & 33 \\
Silt loam & $\mathrm{Tu}$ & 42 \\
Sandy clay loam & $\mathrm{Tl}$ & 49 \\
Silty clay & $\mathrm{Tt}$ & 56 \\
Clay &
\end{tabular}

\subsection{Assessment of groundwater contamina- tion hazard}

The groundwater contamination hazard can be defined as the probability of groundwater in the aquifer to experience negative impacts from given anthropogenic activities to such level resulting the groundwater is unacceptable for human consumptions. Therefore, the most logical approach to assess the occurrence of 
Table 3: Final rating of SVV method and its classification of groundwater vulnerability (Putra, 2007).

\begin{tabular}{|c|c|c|c|}
\hline $\begin{array}{c}\text { Interval } \\
\text { of final } \\
\text { rating }\end{array}$ & $\begin{array}{l}\text { Protective } \\
\text { effective- } \\
\text { ness of } \\
\text { overlying } \\
\text { layers }\end{array}$ & $\begin{array}{l}\text { Intrinsic } \\
\text { ground- } \\
\text { water } \\
\text { vulner- } \\
\text { ability }\end{array}$ & $\begin{array}{l}\text { Relative } \\
\text { residence } \\
\text { time onun- } \\
\text { saturated } \\
\text { zone }\end{array}$ \\
\hline$>70$ & $\begin{array}{l}\text { Very } \\
\text { high }\end{array}$ & Very low & $>25$ years \\
\hline$>65-70$ & High & Low & $\begin{array}{l}10-25 \\
\text { years }\end{array}$ \\
\hline$>35-65$ & Moderate & Moderate & $\begin{array}{c}\text { 3-10 years } \\
\text { Several }\end{array}$ \\
\hline$>24-35$ & Low & High & $\begin{array}{c}\text { months-3 } \\
\text { years }\end{array}$ \\
\hline$<24$ & Very low & Very high & $\begin{array}{c}\text { A few } \\
\text { days-1 } \\
\text { year }\end{array}$ \\
\hline
\end{tabular}

groundwater contamination is to regard it as an interaction between the contaminant loading and groundwater vulnerabiilty at location concerned (Foster \& Hirata, 1988; Morris et al., 2003).

Quantification of contaminant loading potential considers four important factors which are class of contaminants, intensity of contaminants, mode of disposition and duration of contaminant application (Foster \& Hirata, 1998; Johansson \& Hirata, 2002; Chilton et al., 2006). On this study, modified method from Johansson \& Hirata (2002) as conducted by Putra (2007) is applied. The stepwise process of obtaining class of contaminant loading potential based on this method is shown in Figure 3. In order to provide groundwater contamination hazard map, a simple matrix evaluation is used to combine between map of groundwater vulnerability and contaminant loading potential in the research area.

\section{Research Methods}

In order to achieve the objectives of research, field observation was conducted to collect primary data of groundwater condition, unsaturated lithology materials and land use type/activities. Regarding the unsaturated lithology materials, 12 locations of observa- tion were selected (see Figure 4) and grain size analysis of samples were conducted in the Soil Mechanic Laboratory of Civil Engineering, Universitas Gadjah Mada. In case of groundwater, 47 water samples were taken from different land use in the study area, consisting of 44 groundwater samples and 3 surface water samples (see Figure 4). The analysis of the nitrate concentration in groundwater samples were conducted on the Balai Besar Teknik Kesehatan Lingkungan dan Pemberantasan Penyakit Menular Yogyakarta (BBTKL \& PPM) by applying the method Standard (APHA 2012, Section $4500 \mathrm{NO}_{3}^{-} \mathrm{B}$ ). During the water sampling campaign, field measurement was also conducted to measure $\mathrm{pH}$, temperature, TDS, $\mathrm{EC}$, Eh of water and depth to groundwater level. Relate to land use, random observation of land use activities were conducted to collect parameters of contaminant loading potential. Only climatology and groundwater recharge data were collected from previous research.

\section{RESUlts}

\subsection{Nitrate concentration in groundwater}

From the chemical analysis, nitrate concentration in groundwater of the study area is found to be different on each land uses. Nitrate concentration in the groundwater under settlement area are found between $0.09-74.80 \mathrm{mg} / \mathrm{L}$. In addition, rice field area have nitrate concentration in groundwater varied between 0.09-3.40 mg/L, in the non-irrigation agricultural area ranging from $1.52-14.89 \mathrm{mg} / \mathrm{L}$ and in the sand dune area, nitrate concentration on groundwater ranging from 14.89-24.22 mg/L. The distribution of nitrate concentration in the study area are divided into 3 classes, 0-10 mg/L, 10-50 mg/L and 50-100 mg/L as seen in Figure 5.

\subsection{Groundwater wulnerability}

The thickness of unsaturated zone or the depth to groundwater are ranging of 0 to $5 \mathrm{~m}$. The highest value of depth to groundwater located on the south part of the study area and low value of depth to groundwater are found in the middle part of the study area (see Figure 7). The SVV rating of protection from thickness of unsaturated zone in the study area will be only between 1 to 5 points. Based on the 12 locations 

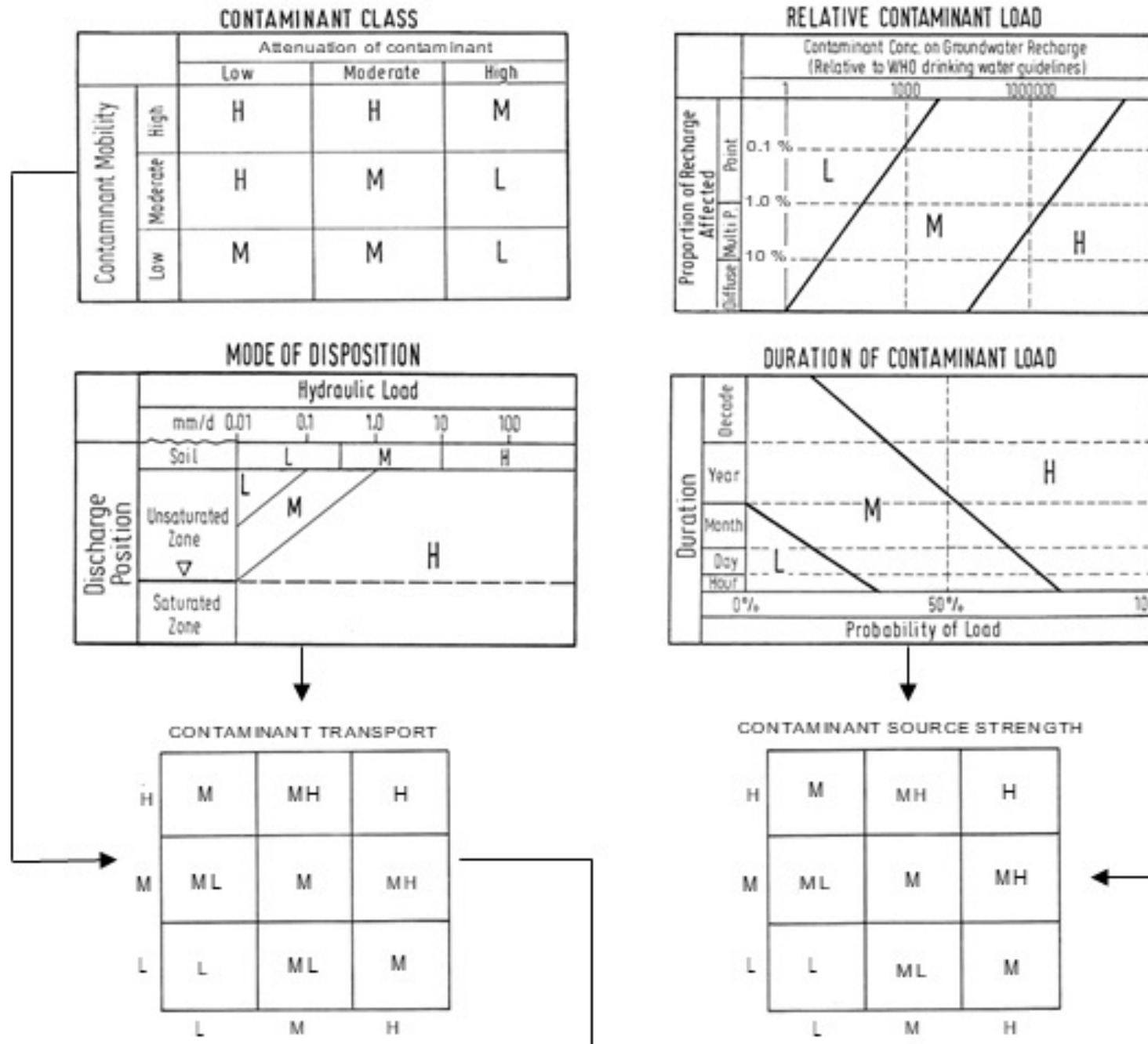

DURATION OF CONTAMINANT LOAD

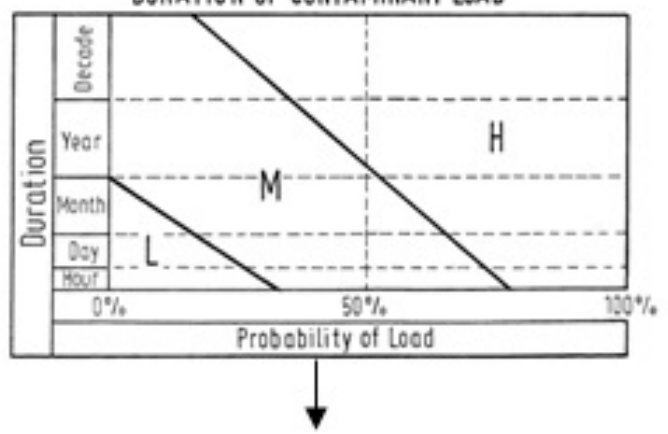

CONTAM INANT SOURCE STRENGTH

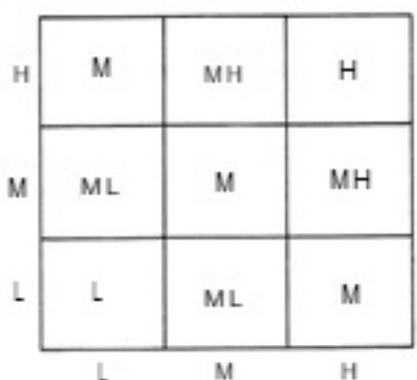

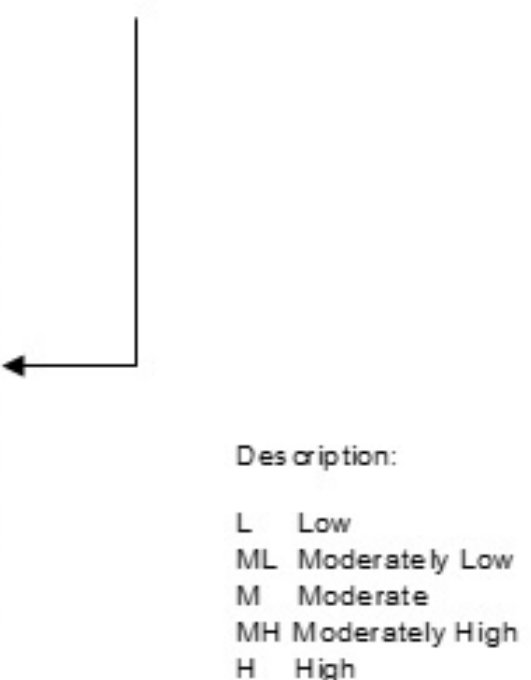

Figure 3: Stepwise processes of the final rating of contaminant loading potential (Johansson and Hirata, 2002; Putra, 2007). 

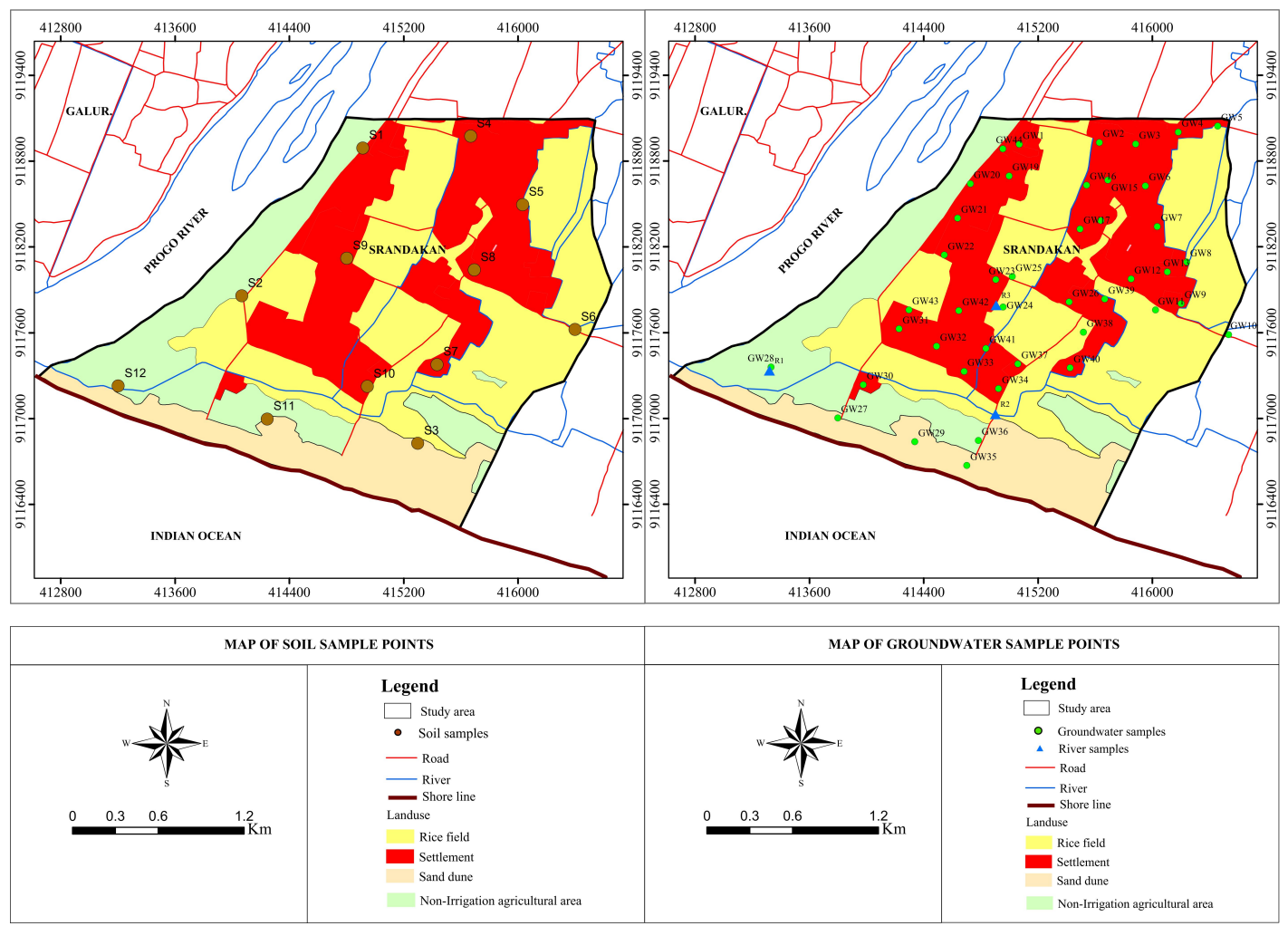

Figure 4: Map of soil and groundwater samples points.

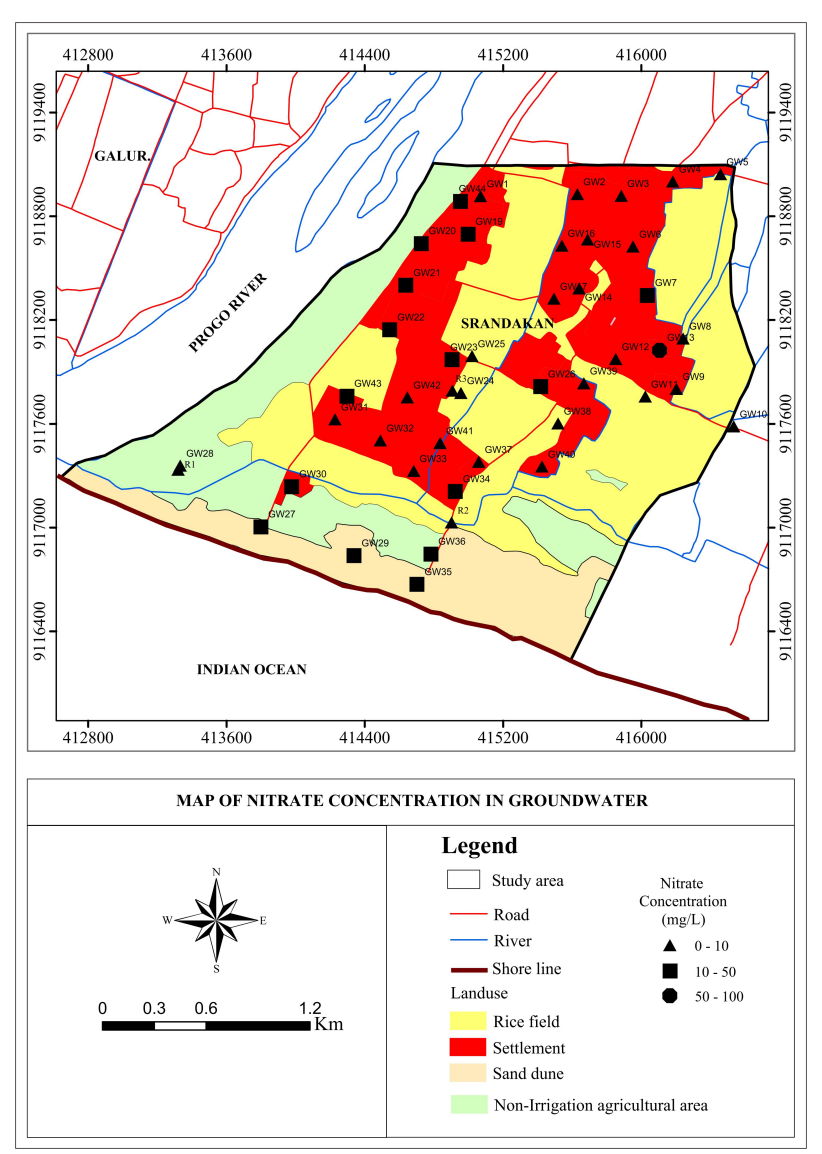

Figure 5: Nitrate concentration in groundwater of the research area. of lithological observation, most of the material of unsaturated zone in the study area are dominated by loamy sand type (6 of 12). Other type of covering material are sandy clay loam (1 of $12)$, sandy loam (2 of 12), sand (2 of 12) and gravelly sand (1 of 12). The lithological condition show clearly that the SVV rating of protection from soil/rock cover are only ranged between 8 to 32 points. By using the recharge data calculated by Kabahari (2014), the recharge rate on the study area is about $95.5 \mathrm{~mm} /$ year, it means that the SVV rating of protection from recharge is 10 points. Sum of all points reveal the total SVV score in the study area ranging of 19 to 49 points. According to Table 3, the class of groundwater vulnerability in the study area will be moderate to very high vulnerability as shown in Figure 6.

Based on the groundwater vulnerability map in study area (Figure 6), moderate vulnerability class is the dominant class of vulnerability followed by very high and high vulnerability area, respectively. In the SVV method, the class of vulnerability also represents the average movement of water in the unsaturated zone. Moderate class means an average vertical movement of water from 3 to 10 years, high class means 


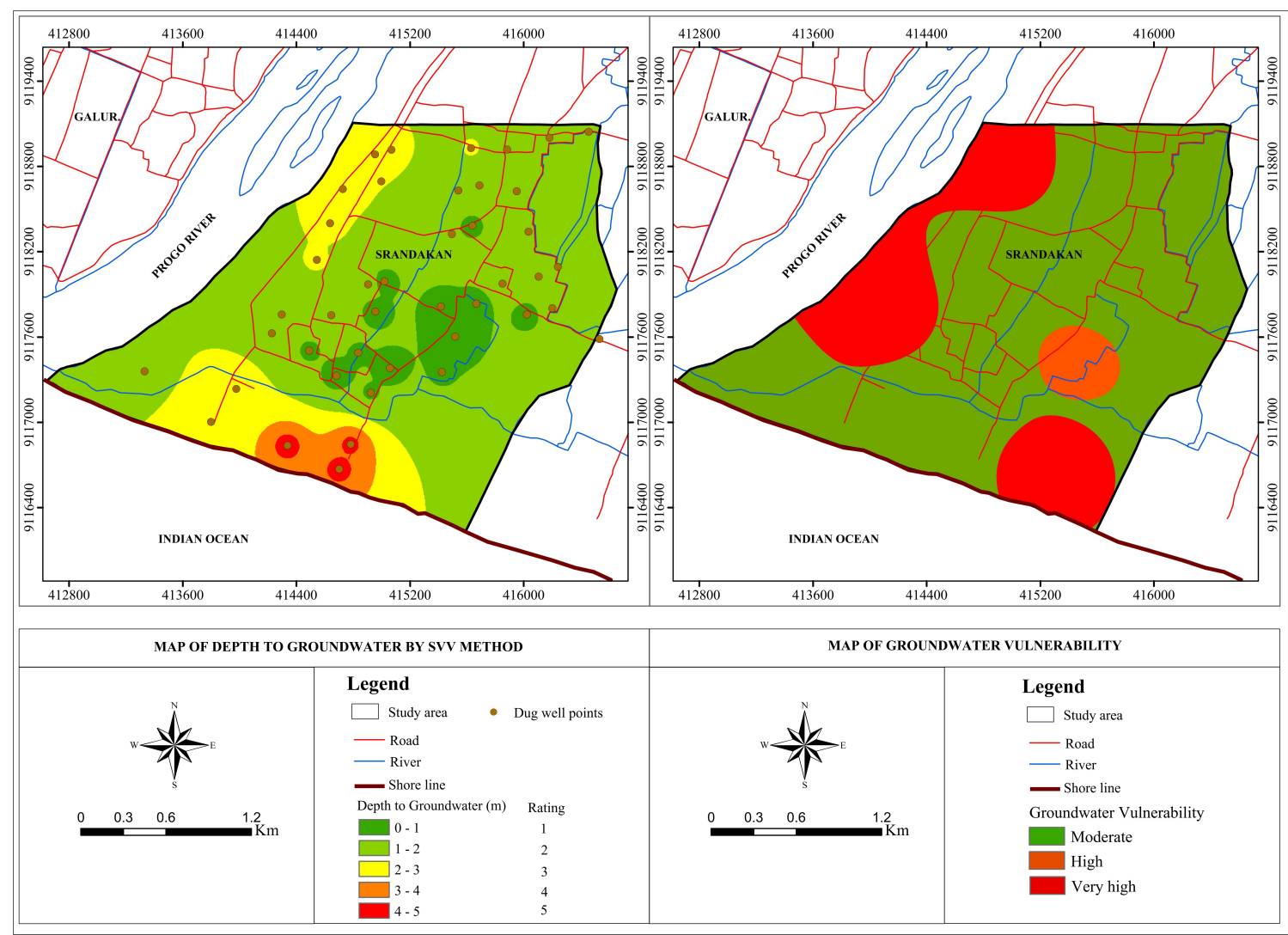

Figure 6: Class of depth to groundwater and groundwater vulnerability map of the study area.

several months to 3 years and very high means few days to 1 year.

\subsection{Nitrate loading potential}

To assess the nitrate loading potential, four parameters of contaminant loading potential were classified depending on their land use type and activities. Different class of parameter (low, moderate, high) are applied on similar land use as the result of 43 field observation on land use site as shown in Appendix 4. Final class of nitrate loading potential from each of land uses are adjusted by following the flow-chart method in the Figure 3, and the results is shown in Figure 7. Based on Figure 7, similar land use type, for example settlement can be classified into several class of nitrate loading potential. This condition occurs due to different type of housing, activities, distance from sanitation and practice of sanitation which found during the field observation.

\subsection{Nitrate contamination hazard}

By combining the map of nitrate loading potential and groundwater vulnerability map of the study area, a map of nitrate contamination haz- ard can be constructed (see Figure 7). The result of nitrate contamination hazard shows a vary class of low to high hazard (see Table 5). The settlement area commonly fall into moderate low to high hazard. In the non-irrigation agricultural and sand dune area are mostly represented by moderate low hazard class and some location of the sand dune area shows also moderate class. In addition, the rice field area classified as low hazard class of nitrate contamination to groundwater.

\section{DisCUSSION}

Based on the result of nitrate analysis, dug wells in the settlement area have the lowest and the highest value of nitrate content on groundwater. The highest value is $74.80 \mathrm{mg} / \mathrm{L}$ was only found in one dug well in the settlement area. This is the only well which contain nitrate above the maximum acceptable concentration level of nitrate in drinking water. According to WHO (2003), maximum concentration of nitrate in drinking water is $50 \mathrm{mg} / \mathrm{L}$. Based on the field observation on the dug well contain the highest concentration of nitrate, the dug well is located very closed to the on-site sanitation 


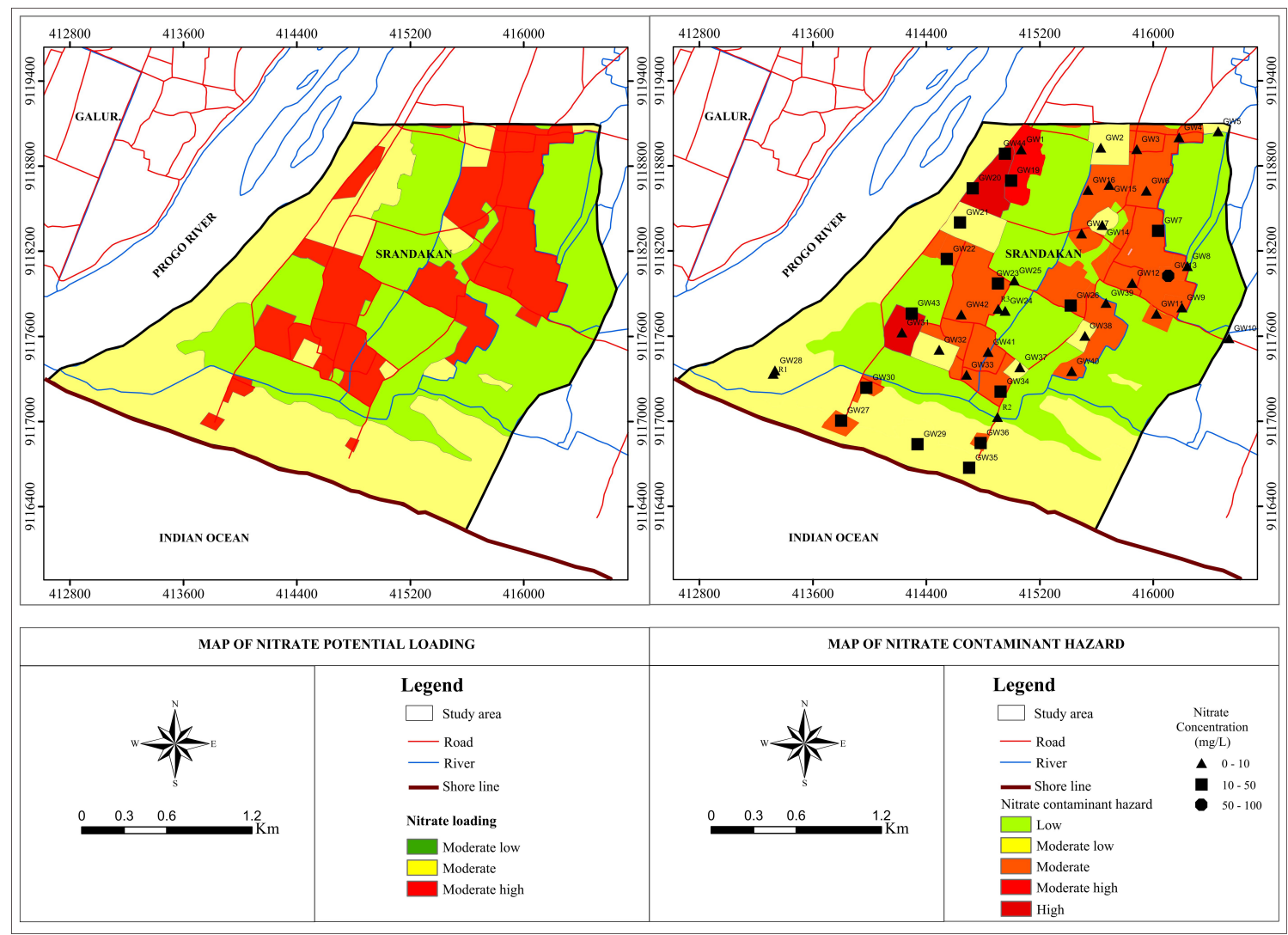

Figure 7: Nitrate loading potential and contaminant hazard to groundwater in the research area.

system. However, most concentration of nitrate on groundwater under settlement area are less than $10 \mathrm{mg} / \mathrm{L}$ which is quite similar to the result of Gunadarma (2016). For non irrigated and sand dunes area, the nitrate concentration on groundwater are commonly 10 to $50 \mathrm{mg} / \mathrm{L}$, and according to the field observation this can be relate to agriculture practice of shrimp pond in the non irrigated area and tourism activities along the beaches where there are a lot of small kiosk or restaurants providing food and drink also toilet which presumably built with inappropriate on-site sanitation system. In the case of irrigated rice field, it is found that the dug wells on this land use contain low nitrate of less than $10 \mathrm{mg} / \mathrm{L}$. Explanation on this may be relate to the small amount of chemical fertilizer that used by the farmer as common in Indonesia (Putra, 2007).

Regarding the groundwater vulnerability, the dominance moderate class of vulnerability may become the reason why in the settlement area, the content of nitrate is commonly low despite most of the villagers on this area are using onsite sanitation system and shallow groundwater system. The wide distribution of sandy loam and loamy sand which part of Wates Formation in the study area, become an important parameter to protect the shallow groundwater from contamination although the groundwater is very shallow on this region.

The important question relate to the groundwater contamination hazard is how good the map can predict the contamination hazard. Therefore, in this research, a comparison between class of nitrate contamination hazard and median value of nitrate concentration on each class is compared (see Figure 8). From this figure, it can be seen that there are a positive correlation between class of hazard and the median value of nitrate content in groundwater. In the high hazard area, the median value is $31.14 \mathrm{mg} / \mathrm{L}$. In addition, the median value for other classes in order are moderate high $8.15 \mathrm{mg} / \mathrm{L}$, moderate $6.56 \mathrm{mg} / \mathrm{L}$, moderate low $6.27 \mathrm{mg} / \mathrm{L}$ and low $3.4 \mathrm{mg} / \mathrm{L}$, respectively. Although the comparison shows positive correlation, but the value of nitrate on each classes are actually not very differ for moderate low to moderate high. This can be occurred due to problem on defining the class of parameters in the nitrate loading potential method. Even 
though, there are 43 observations site of land use in the study area, it is presumably a lot of difference activities on other unobserved locations. Another reason may be the combination of groundwater vulnerability and nitrate loading potential may not be easily taken as a simple matrix relationship as already show by Putra (2007). Despite all of this weakness, this research has successfully show that even by applying simple approach as explained on this paper, the map of nitrate contamination hazard can predict the relative concentration of nitrate in different classes of contamination hazard.

\section{CONCLUSIONS}

According to the result and discussion, some conclusion can be drawn with respect to the objectives as following: 1) Nitrate concentration in the groundwater of the study area ranging from $0.09-74.80 \mathrm{mg} / \mathrm{L}$, high content of nitrate on groundwater is found in the settlement area and low content of nitrate commonly found in the irrigated rice field area. 2) Groundwater vulnerability assessment by SVV method is successfully reveal moderate, high and very high class of vulnerability from contamination in the study area, in which moderate class is the dominance one, followed by very high and high vulnerability due to shallow groundwater and the sandy dominated overlying material. 3) Finally, the assessment of nitrate contaminant hazard show that the study area are classified into five zones of low, moderate low, moderate, moderate high and high hazard. The classes of hazard are correlate with the median value of nitrate concentration in groundwater. The high and moderate high hazard area are distributed commonly in the settlement area.

\section{ACKNOWLEDGEMENTS}

The first author's like to thanks to Indonesian Government whose support for the master study and research activities in the Universitas Gadjah Mada, Indonesia.

\section{REFERENCES}

ARGOSS (2001) Guidelines for Assessing the Risk to Groundwater from On Site Sanitation, British Geological Survey Commisioned Report, $\mathrm{CR} / 01 / 142,97 \mathrm{p}$.

Chilton, J., Schmoll, O and Appleyard, S. (2006) Assessment of Groundwater Pollution Potential, In:
Schmoll, O, Howard, G, Chilton, J and Chorus, I. (ed) Protecting Groundwater for Health: Managing Quality of Drinking Water Sources, WHO Drinking Water Quality Series, IWA Publishing, p. 375-410.

Fathmawati, Fachiroh, J., Gravitiani, E., Sarto and Husodo, A.H. (2017), Nitrate in drinking water and risk of colorectal cancer in Yogyakarta, Indonesia, Journal of Toxicology and Environmental Health; Part A, Vol.80, Issue-2, 2017.

Foster, S., and Hirata, R. (1988) Groundwater Pollution Risk Assessment; A Methodology Using Available Data, PAN American Center For Sanitary Engineering and Environmental Sciences (CEPIS), Lima, Peru.

Gunadarma, A.E. (2016) Identifikasi Pencemaran Air Tanah di Wilayah Samas dan Sekitarnya, Srandakan, Kab. Bantul, Daerah Istimewa Yogyakarta, Indonesia., Skripsi, Universitas Gadjah Mada.

Johansson, P.O., and Hirata, R. (2002) Groundwater Contaminant Inventory: rating of contamination source, Prepared for the international hydrological program, UNESCO. 5:63-73.

Kabahari, H. (2014) Regional Groundwater flow modeling in Samas area, Bantul district, Yogyakarta Special Region, Indonesia (Bachelor thesis), Gadjah Mada University.

MacDonald and Partners (1984) Greater Yogyakarta groundwater resources study: Groundwater (Vol. 3). Groundwater Development Project (P2AT). Ministry of Public Works, Government of the Republic of Indonesia.

Morris, B.L., Lawrence, A.R., Chilton, P.J.C., Adams, B., Calow, R.C., and Klinck, B.A. (2003) Groundwater and its susceptibility to degradation: A global assesment of the problem and options for management. Early Warning and Assesment Report Series, RS.03-3. United Nations Environment Programme, Nairobi, Kenya.

Putra, D. P. E. (2003) Intergrated water resources management in Merapi-Yogyakarta Basin (Project SEED-Net No. UGM 0104), Gadjah Mada University, Yogyakarta.

Putra, D. P. E. (2007) The Impact of urbanization on groundwater quality: A case study in Yogyakarta City-Indonesia. In: Mitteilungen zur Ingeneiurgeologie und Hydrogeology, 96, Aachen.

Putra, D.P.E. (2010) Estimation, reality and trend of groundwater nitrate concentration under unsewered area of Yogyakarta City, Indonesia, Journal of Southeast Asian Applied Geology, Jan-Apr 2010, Vol. 2(1). p 20-27.

WHO (2003), Nitrate and Nitrite in Drinking Water; Background Document for Development of WHO Guidelines for Drinking-water Quality, World Health Organization, Geneva. 
Table 4: Potential of groundwater contaminant loading.

\begin{tabular}{|c|c|c|c|c|c|c|}
\hline No. & Land use activities & $\begin{array}{c}\text { Class of } \\
\text { contaminant } \\
\text { (Nitrate) }\end{array}$ & $\begin{array}{c}\text { Mode of } \\
\text { disposition }\end{array}$ & $\begin{array}{c}\text { Relative } \\
\text { contaminant } \\
\text { load }\end{array}$ & $\begin{array}{c}\text { Duration of } \\
\text { contaminant } \\
\text { load }\end{array}$ & $\begin{array}{c}\mathrm{NO}_{3}^{-} \text {potential } \\
\text { groundwater } \\
\text { contamination } \\
\text { load }\end{array}$ \\
\hline 1 & House & High & Low & Low & High & Moderate \\
\hline 2 & House & High & Low & Low & High & Moderate \\
\hline 3 & House & High & High & Low & High & Moderate high \\
\hline 4 & House & High & High & Low & High & Moderate high \\
\hline 5 & House & High & Low & Low & High & Moderate \\
\hline 6 & House & High & Moderate & Low & High & Moderate high \\
\hline 7 & House & High & High & Low & High & Moderate high \\
\hline 8 & House & High & High & Low & High & Moderate high \\
\hline 9 & House & High & High & Low & High & Moderate high \\
\hline 10 & House & High & High & Low & High & Moderate high \\
\hline 11 & House & High & Moderate & Low & High & Moderate high \\
\hline 12 & House & High & High & Low & High & Moderate high \\
\hline 13 & House & High & High & Low & High & Moderate high \\
\hline 14 & House & High & Moderate & Low & High & Moderate high \\
\hline 15 & House & High & High & Low & High & Moderate high \\
\hline 16 & House & High & Low & Low & High & Moderate \\
\hline 17 & House & High & Moderate & Low & High & Moderate high \\
\hline 18 & House & High & Low & Low & High & Moderate \\
\hline 19 & House & High & Moderate & Low & High & Moderate high \\
\hline 20 & House & High & Low & Low & High & Moderate \\
\hline 21 & House & High & Moderate & Low & High & Moderate high \\
\hline 22 & House & High & High & Low & High & Moderate high \\
\hline 23 & Cow \& goat farm & High & Low & Low & Moderate & Moderate low \\
\hline 24 & Cow \& goat farm & High & Low & Low & Moderate & Moderate low \\
\hline 25 & House & High & High & Low & High & Moderate high \\
\hline 26 & House & High & High & Low & High & Moderate high \\
\hline 27 & Shrimp farm & High & High & Low & Moderate & Moderate \\
\hline 28 & $\begin{array}{l}\text { Restaurant near the } \\
\text { beach }\end{array}$ & High & Low & Low & Moderate & Moderate \\
\hline 29 & House & High & Moderate & Low & High & Moderate high \\
\hline 30 & House & High & High & Low & High & Moderate high \\
\hline 31 & House & High & Low & Low & High & Moderate \\
\hline 32 & House (goat farm) & High & Low & Low & Moderate & Moderate low \\
\hline 33 & House & High & High & Low & High & Moderate high \\
\hline 34 & $\begin{array}{l}\text { Restaurant near the } \\
\text { beach }\end{array}$ & High & Moderate & Low & Moderate & Moderate \\
\hline 35 & House & High & Moderate & Low & High & Moderate high \\
\hline 36 & House & High & Low & Low & High & Moderate \\
\hline 37 & Cow farm & High & Low & Low & Moderate & Moderate low \\
\hline 38 & House & High & Moderate & Low & High & Moderate high \\
\hline 39 & House & High & Low & Low & High & Moderate \\
\hline 40 & House & High & Moderate & Low & High & Moderate high \\
\hline 41 & House & High & High & Low & High & Moderate high \\
\hline 42 & House & High & High & Low & High & Moderate high \\
\hline 43 & House & High & Moderate & Low & High & Moderate high \\
\hline
\end{tabular}


Table 5: Result of groundwater contaminant hazard assessment.

\begin{tabular}{|c|c|c|c|c|c|c|}
\hline No. & $X$ & Y & Land use activities & $\begin{array}{c}\text { Potential } \\
\text { groundwater } \\
\text { contamination load }\end{array}$ & $\begin{array}{l}\text { Groundwater } \\
\text { vulnerability }\end{array}$ & $\begin{array}{c}\text { Groundwater } \\
\text { pollution hazard }\end{array}$ \\
\hline 1 & 415069 & 9118917 & House & Moderate & Very high & Moderate high \\
\hline 2 & 415629 & 9118929 & House & Moderate & Moderate & Moderate low \\
\hline 3 & 415883 & 9118918 & House & Moderate high & Moderate & Moderate \\
\hline 4 & 416182 & 9119002 & House & Moderate high & Moderate & Moderate \\
\hline 5 & 416457 & 9119044 & House & Moderate & Moderate & Moderate low \\
\hline 6 & 415952 & 9118626 & House & Moderate high & Moderate & Moderate \\
\hline 7 & 416035 & 9118342 & House & Moderate high & Moderate & Moderate \\
\hline 8 & 416241 & 9118094 & House & Moderate high & Moderate & Moderate \\
\hline 9 & 416202 & 9117803 & House & Moderate high & Moderate & Moderate \\
\hline 10 & 416022 & 9117758 & House & Moderate high & Moderate & Moderate \\
\hline 11 & 415851 & 9117975 & House & Moderate high & Moderate & Moderate \\
\hline 12 & 416105 & 9118025 & House & Moderate high & Moderate & Moderate \\
\hline 13 & 415639 & 9118384 & House & Moderate high & Moderate & Moderate \\
\hline 14 & 415689 & 9118666 & House & Moderate high & Moderate & Moderate \\
\hline 15 & 415539 & 9118631 & House & Moderate high & Moderate & Moderate \\
\hline 16 & 415494 & 9118325 & House & Moderate & Moderate & Moderate low \\
\hline 17 & 414768 & 918267 & House & Moderate high & Moderate & Moderate \\
\hline 18 & 414997 & 9118696 & House & Moderate & Very high & Moderate high \\
\hline 19 & 414726 & 9118641 & House & Moderate high & Very high & High \\
\hline 20 & 414637 & 9118400 & House & Moderate & Moderate & Moderate low \\
\hline 21 & 414544 & 9118143 & House & Moderate high & Moderate & Moderate \\
\hline 22 & 414905 & 9117970 & House & Moderate high & Moderate & Moderate \\
\hline 23 & 414956 & 9117779 & Cow \&Goat Farm & Moderate low & Moderate & Low \\
\hline 24 & 415019 & 9117992 & Cow \&Goat Farm & Moderate low & Moderate & Low \\
\hline 25 & 415417 & 9117814 & House & Moderate high & Moderate & Moderate \\
\hline 26 & 413798 & 9117004 & House & Moderate high & Moderate & Moderate \\
\hline 27 & 413331 & 9117359 & Shrimp farm & Moderate & Moderate & Moderate low \\
\hline 28 & 414338 & 9116837 & $\begin{array}{l}\text { Restaurant near the } \\
\text { beach }\end{array}$ & Moderate & Moderate & Moderate low \\
\hline 29 & 413977 & 9117236 & House & Moderate high & Moderate & Moderate \\
\hline 30 & 414228 & 9117626 & House & Moderate high & Very high & High \\
\hline 31 & 414490 & 9117505 & House & Moderate & Moderate & Moderate low \\
\hline 32 & 414682 & 9117329 & House (Goat farm) & Moderate low & Moderate & Low \\
\hline 33 & 414924 & 9117208 & House & Moderate high & Moderate & Moderate \\
\hline 34 & 414702 & 9116671 & $\begin{array}{l}\text { Restaurant near the } \\
\text { beach }\end{array}$ & Moderate & Moderate & Moderate low \\
\hline 35 & 414782 & 9116846 & House & Moderate high & Moderate & Moderate \\
\hline 36 & 415059 & 9117381 & House & Moderate & Moderate & Moderate low \\
\hline 37 & 415517 & 9117603 & Cow farm & Moderate low & High & Moderate low \\
\hline 38 & 415667 & 9117834 & House & Moderate high & Moderate & Moderate \\
\hline 39 & 415425 & 9117353 & House & Moderate & High & Moderate \\
\hline 40 & 414836 & 9117490 & House & Moderate high & Moderate & Moderate \\
\hline 41 & 414646 & 9117753 & House & Moderate high & Moderate & Moderate \\
\hline 42 & 414296 & 9117759 & House & Moderate high & Very high & High \\
\hline 43 & 414953 & 9118885 & House & Moderate high & Very high & High \\
\hline
\end{tabular}




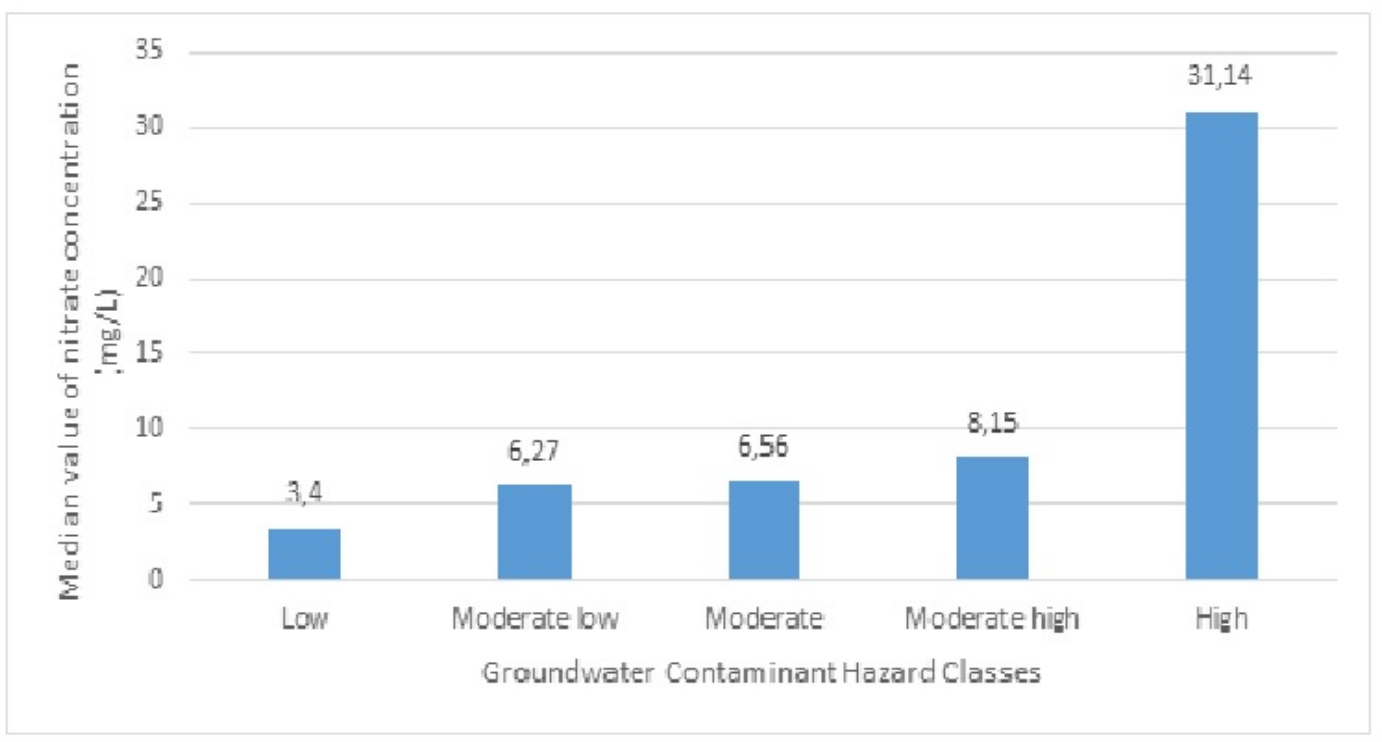

Figure 8: Correlation between median value of nitrate concentration and groundwater contaminant hazard class. 